ISSN 1112-9867

Available online at

http://www.jfas.info

\title{
DESERT TRUFFLES FROM NORTHEASTERN ALGERIAN COASTAL DUNES: ECOLOGY, IDENTIFICATION AND SYMBIOSIS
}

\author{
A. Dafri * and A. Beddiar \\ Departement of Biology, Badji Mokhtar University, PO Box 12, Annaba, Algeria
}

Received: 09 February 2016 / Accepted: 12 December 2016 / Published online: 01 January 2017

\begin{abstract}
For several years, greater attention has been focused on desert truffles of Southern and Western Algeria. The present work is the first to be concerned on desert truffles from northeastern Algerian littoral dunes. The aim of this work is to describe northeastern Algerian truffle fields, identify collected truffle species and their symbiotic plant partner. We required two years field prospections, soil analysis, ascocarps morpho-anatomical and molecular analysis. We concluded that truffle fields share an acid sandy-loam soil and a notable abundance of many subspecies of Tuberaria gutatta (L.) Fourr. 1868, proved as desert truffles symbiotic partner. Two sandy truffle species are recorded: Terfezia arenaria (Moris) Trappe (1971) and Tuber gennadii (Chatin) Patouillard 1903. This data is the first to review knowledge on northeastern desert truffles and to report Tuber gennadii in Algeria.
\end{abstract}

Keywords: Northeaster Algeria, littoral dunes, desert truffles, Terfezia arenaria, Tuber gennadii, Tuberaria gutatta.

Author Correspondence, e-mail: dafria23@gmail.com doi: http://dx.doi.org/10.4314/jfas.v9i1.11 


\section{INTRODUCTION}

Throughout the Mediterranean basin, North Africa, Saudi Arabia and the United Arab Emirates, desert truffles play an important role in both folklore and cuisine [1, 2]. They were traditionally used in trachoma treatment [3] and have been proved worthwhile in ecosystems maintain [4]. The term "Desert truffles" includes species of different hypogeous Ascomycetes genera, among which Terfezia, Tirmania, Picoa and some Tuber species [5]. Though their gastronomical value is certainly no match for that of "true" truffles, desert truffles are by no means less interesting in historical terms. They have been eaten by the indigenous people of several countries, from prehistoric times and were probably served at the royal feasts of the Pharaohs [6]. Thus, there should be no doubt that these fascinating hypogeous fungi have been known and appreciated as a valuable commodity long before European truffles.

Likewise, traditionally use of those antique jewels in the treatment of ocular diseases, such as trachoma, is not to be neglected $[3,7]$. This antimicrobial activity mentioned by the prophet (PBUH) many centuries ago, has been proved in 1980 by the Egyptian ophthalmologist Dr. Al-Marzooky, who found that the water extracted from truffles stops the formation of fibrous tissue in the infected area to prevent the occurrence of fibrosis in cases of eye trachoma [8]. Besides their culinary and medicinal properties, they play an important role in terrestrial ecosystems and their potential use as mycorrhizal partners has been encouraging both in accelerating plant growth and reducing their mortality rate [4].

Desert truffles that have been evolved in hard and hostile conditions, of arid and semi-arid regions of the Middle east, North Africa and Eastern Mediterranean, must this name to their geographical distribution which has longer been considered typical of desert territories $[5,7,9]$ which is basically what the present paper would refute.

In Algeria, greater attention has been focused on Southern and Western sands $[10,11]$ no studies are as yet, however, available on the northeastern sands of the country. Therefore, the current article is the first to review knowledge on ecology, symbiosis and diversity of desert truffles of those coastal dunes, where collection and sale provides a seasonal trade that creates a local truffle market under development.

Despite their countless benefits, desert truffles of the studied region are still less known and 
little appreciated by the majority of people but a small part of inhabitants who leave near truffle fields. Hence, this work is carried out in order to highlight the being of these renowned mushrooms in the studied region, bring out their ecological growth conditions and show up the prevailing species and their symbiotic partner, a step that seems to be indispensable before any other research on those mysterious tubers.

\section{MATERIAL AND METHODS}

\subsection{Study zone presentation}

Littoral dunes of northeastern Algeria are located in the province of El-Tarf known for its "National Park of El-kala", created in 1983 and recognised as a biosphere reserve by UNESCO in 1990. This province has hot-summer Mediterranean climate characterised by a cold wet winter and hot dry summer. The average annual precipitation is about 600 to 1000 $\mathrm{mm}$, concentrated in autumn, winter and spring. January is the wettest month of the year. The hot season could extend for four to six months. August is the hottest one with an average temperature of $8^{\circ} \mathrm{C}$ as minima and $29.7^{\circ} \mathrm{C}$ as maxima $[12,13]$. The average altitude of El-Tarf is about $104 \mathrm{~m}$. It has a very rich hydrographical network in permanent and temporary valleys, diverse ecosystems and a remarkable biodiversity.

The studied coastal dunes, part of which belongs to the national park, extend over a length of $40 \mathrm{~km}$ from Oued Mafragh westward to the Tonga basin in the east and till the bottom of Djebel Segleb southwards. They are gradually straighter and more stable going from sea toward inland where fossilisation degree is much greater. According to Joleaud [14], this region comports a series of quaternary marine sediments that cover ancient red sands. It could be subdivided on three different physical domains that are: the plain of Ben M'hidi in the North, the mountains domain in the South and the humid lakes domain in the east [15].

The truffle field locating amongst the dunes was based on the knowledge of the harvesters and sellers and the presence of truffles plant partner. The localization of the fields was carried out using a Garmin 60 global positioning system (GPS).

\subsection{Sampling and analysis}

Soil sampling was performed by combining elements from three different spots in each site. It was conducted at a depth that does not exceed $20 \mathrm{~cm}$. The collected samples were studied in 
the lab to determine the soil physicochemical characteristics, by analysing several parameters: $\mathrm{pH}$ level, electrical conductivity, carbon and organic matter, texture, phosphorus and total nitrogen using the methods described by Baize [16].

Finding out the desert truffles symbiotic plant partner is the result of countless ground prospections, and root analysis, enhanced by traditional knowledge of desert truffle hunters as well as previous studies of many experts on north African desert truffles [17, 18].

Desert truffle picking is realised in several ways, for surface near ascocarps, fissured ground could indicate desert truffle presence beneath [19]. When climate conditions and depth of tubers do not allow the soil crack, harvesting refers to the host plant abundance in a small plot of ground generally very loose (Fig. 1). In this region, experimented hunters, mainly men and young people, neither use animals like in Europe, nor sticks like in Morocco, they do not need more than the index and middle fingers to confirm the presence of the ascocarp. Once they detect the treasured ascomata, they generally use hands, or rarely a small hand rake, to gently uncover the soil and pluck it.

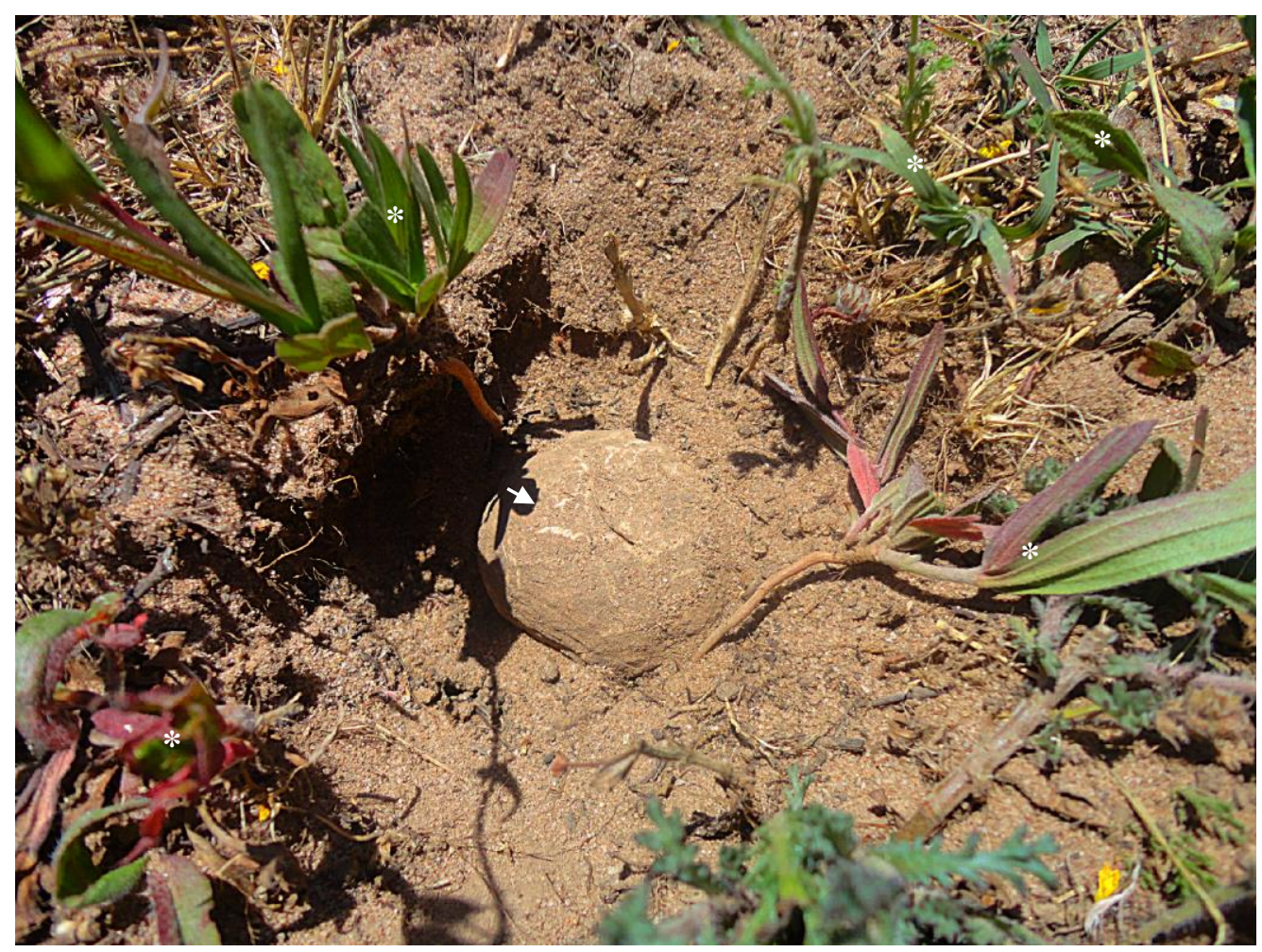

Fig. 1: Desert truffle sampling (Photograph $\odot$ DAFRI A)

The picture shows very loose soil, desert truffle ascocarp and truffle symbiotic partner $(*)$ 


\subsection{Species identification strategies}

Morphological identification has relied on keys elaborated for the north African desert truffles by many investigators $[18,20]$. That was mainly a morpho-anatomical classification based on several criteria, namely: colour and shape of peridium, colour and morphology of gleba, colour and shape of ascospores and asci, size of ascospores and asci estimated by calculating the average of ten elements. One more important criteria was the number of ascospores within an ascus, which was carried out using light microscopy by crushing a thin fragment of gleba between slide and cover with a drop of distilled water and a dye (Cotton blue / Congo red) if necessary.

Molecular authentication was based on the amplification of the internal transcribed spacer (ITS) region from fresh ascocarps. DNA analysis was done according to the methodology of Bordallo et al (2013) [21]. PCR reactions were performed in a mastercycler gradient thermocycler (Eppendorf, Hamburg, Germany) with the following cycling parameters: an initial denaturalization step for $2 \mathrm{~min}$ at $94^{\circ} \mathrm{C}, 30 \mathrm{~s}$ at $94^{\circ} \mathrm{C}, 1 \mathrm{~min}$ at $60^{\circ} \mathrm{C}$, and $1 \mathrm{~min}$ at $72^{\circ} \mathrm{C}$, and a final extension at $72^{\circ} \mathrm{C}$ for $4 \mathrm{~min}$. PCR products were sequenced at the molecular biology service of the University of Murcia, Spain. BioEdit program [22] was used to obtain the consensus sequence of each sample. Sequences were deposited in GenBank (NCBI) under accession numbers in table 1 below.

Table 1: Accession numbers of analysed sequences of Terfezia arenaria

\begin{tabular}{cc}
\hline Sample & Accession number \\
\hline 1 & KP217812 \\
2 & KP217813 \\
3 & KP217814 \\
4 & KP217815 \\
5 & KP217816 \\
6 & KP217817 \\
7 & KP217818 \\
\hline
\end{tabular}

To identify the species, their sequences were compared to those of other DNA sequences in GenBank (NCBI) using the nucleotide basic local alignment search tool (BLAST) available 
online [23]. The sequence alignment was carried out with ClustalW MEGA software, version 4 [24], following the default options. MEGA v.4 editor was used to make manual adjustment and evolutionary history based on maximum parsimony (MP) [25] and minimum evolution (ME) [26] methods. The tree was obtained using the Close-Neighbour-Interchange algorithm. Evolutionary history was interfered using the maximum parsimony method. All gaps were eliminated before the alignment of sequences (complete deletion option) and phylogenetic analyses were conducted on MEGA4.

\section{RESULTS}

\subsection{Description and distribution of desert truffle fields}

Prospecting revealed seven identified truffle fields distributed as on the geographical card hereafter (Fig.2).

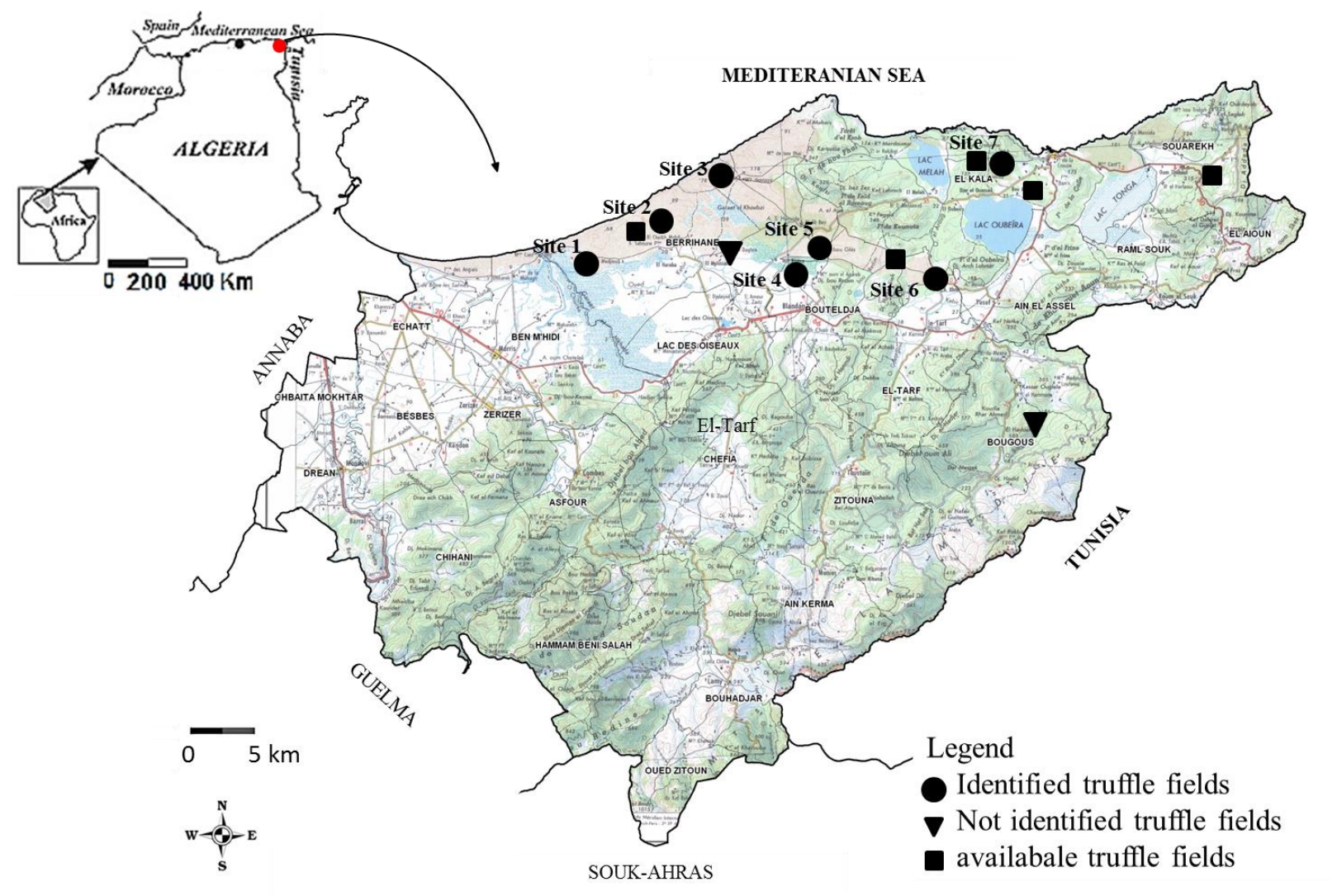

Fig. 2: Map of location of desert truffle fields

All sites are grazing lands of low altitude $(25-70 \mathrm{~m})$, characterised by a Mediterranean climate. They belong to humid or sub-humid warm bioclimatic levels, wherein precipitation ranges between 600 and $1000 \mathrm{~mm}$ a year. 


\subsection{Physicochemical characteristics of truffle field soils}

The study of truffles ecology has been started with the study of physicochemical characteristics of truffle field soils. The results of soil analyses are summarised in table 2.

Table 2: Soil physicochemical characteristics

\begin{tabular}{|c|c|c|c|c|c|c|c|}
\hline Sites & 1 & 2 & 3 & 4 & 5 & 6 & 7 \\
\hline $\mathrm{pH}$ level & 6.12 & 5.85 & 6.62 & 5.79 & 5.64 & 5.50 & 5.39 \\
\hline $\begin{array}{l}\text { Electrical conductivity } \\
\text { (Milli siemens) }\end{array}$ & 0.79 & 1.04 & 0.34 & 1.52 & 1.40 & 1.03 & 0.25 \\
\hline Organic matter $(\%)$ & 3.37 & 3.16 & 1.05 & 5.91 & 0.21 & 2.95 & 0.21 \\
\hline Total nitrogen $(\mathrm{mg} / \mathrm{kg} \mathrm{N})$ & 3.6 & 14.8 & 2.2 & 1.8 & 3.6 & 4.5 & 4.1 \\
\hline $\begin{array}{l}\text { Total phosphorus } \\
\mathrm{P}(\mathrm{mg} / \mathrm{kg} \mathrm{P})\end{array}$ & 21.6 & 10.6 & 7.8 & 6.6 & 7.6 & 22.2 & 1.6 \\
\hline $\begin{array}{l}\text { Assimilable phosphorus } \\
\mathrm{P}_{2} \mathrm{O}_{5}(\mathrm{mg} / \mathrm{kg})\end{array}$ & 48.0 & 24.0 & 18.0 & 16.0 & 64.0 & 52.0 & 3.8 \\
\hline Soil texture & \multicolumn{7}{|c|}{ Sandy-loam } \\
\hline
\end{tabular}

\subsection{Desert truffle symbiotic partner}

It has been proven that studied desert truffles grow in association with Tuberraria gutatta (L.) Fourr., 1868, for its common name Rockrose. It is a plant of the family Cistaceae ranked in the order Violales. It is greatly distributed in the region where it is so-called E'zahoo, known in the other regions of the country by: Qessis E'terfess, Oom E'terfess, E'rgeeg... (Fig. 3). The plant is an annual or sub-perennial herb which typically grows in low scrublands, frequently on limestone and often close to the sea. It has simple or branched pilose stem that could reach $30 \mathrm{~cm}$ high. Basal leaves are elliptical, forming a rosette, usually dead at flowering time. Cauline leaves are entire, opposite, exstipulate, sessile, elliptic to lanceolate, 

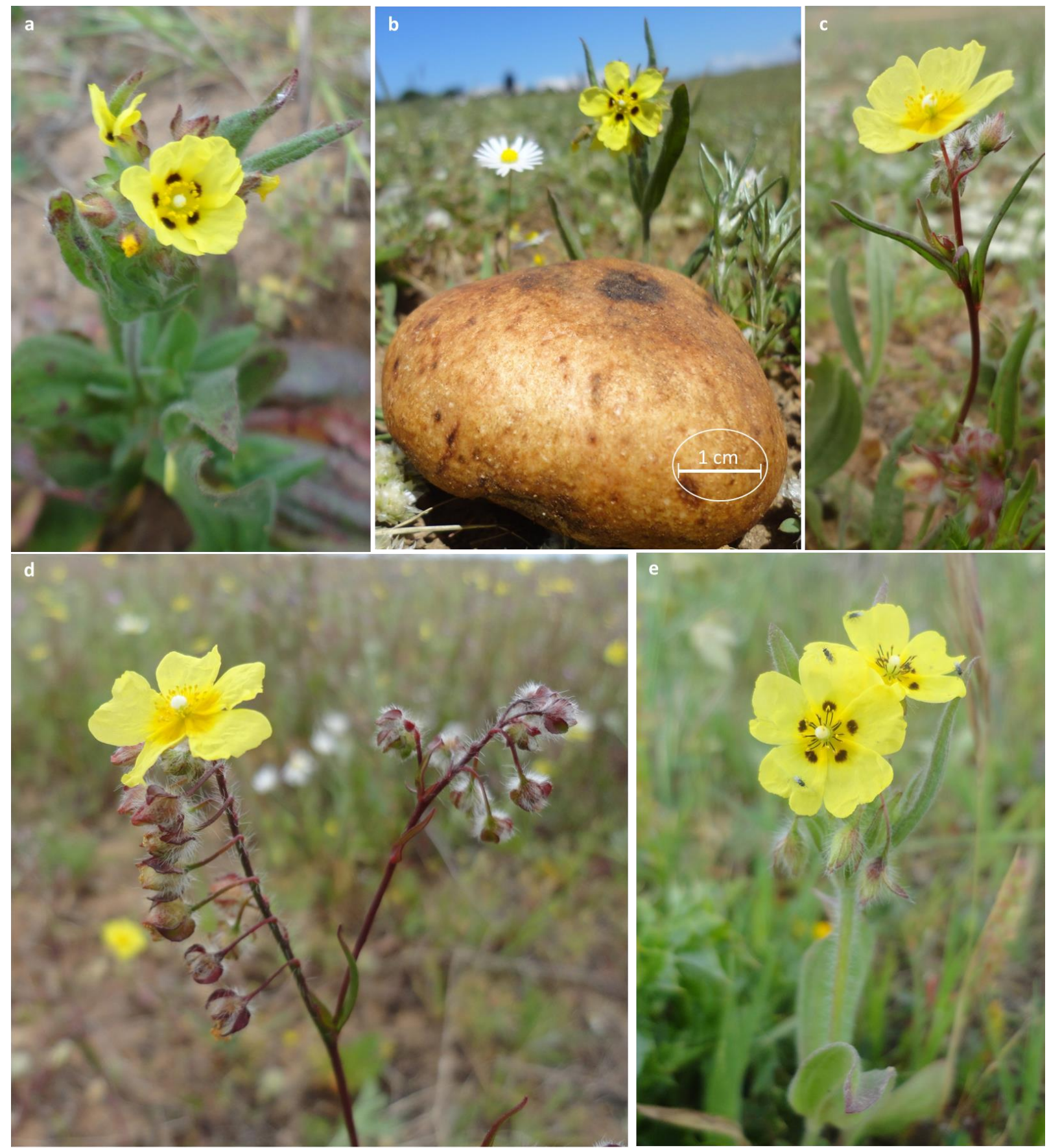

Fig. 3: Tuberraria guttata (L.) Fourr., 1868 flower variation (Photograph @ DAFRI A)

a, b: maculated petals and yellow stamens, $\mathbf{c}, \mathbf{d}$ : non-maculated petals, e: maculated petals and black stamens. This subspecies is rarely found.

3-veined, subacute to obtuse for the lower, while shorter and narrower, alternate, lanceolate to linear with or without linear stipules for the upper fewer ones. Yellowish flowers are very variable with sometimes characteristic spots at petal bases (Fig. 3 a, b, e). Petals are very variable in size and intensity of colour, rarely with dark stamens (Fig. 3 e). 
The present studied fields show much higher frequency of non-spotted rockroses (Fig. 3 c, d) against the spotted ones observed during spring 2012 only in sites 4 and 7 (Fig. 3 a, b) and in May 2014 only in site 1 (Fig. 3 e).

\subsection{Truffle identified species}

Two species were identified: Terfezia arenaria (Moris) Trappe (1971) and Tuber gennadii (Chatin) Patouillard 1903 (Fig. 5-6).

\subsubsection{Terfezia arenaria (Moris) Trappe (1971)}

This species could be harvested from almost all sites. It has weak smell and taste, and is potato shaped, often pedunculated with different size (between 3 and $12 \mathrm{~cm}$. Fig. 5 a, b). This species is characterised by a thick peridium, white at first and dark brown at maturity. The gleba is whitish at the beginning, then becoming pink with pale veins (Fig. 5 c). It contains globose to subglobose asci whose sizes are about 65-92 $\mu \mathrm{m}$ (Fig. 5 e). One ascus comprises generally eight yellow ochre spherical ascospores averaging 20-30 $\mu \mathrm{m}$ in diameter and decorated with truncated warts up to $7 \mu \mathrm{m}$ tall (Fig. $5 \mathrm{f}$ ).

The PCR product of this species obtained with primers pair ITS1 and ITS4 shows different potential subspecies of Terfezia arenaria (Fig. 4).

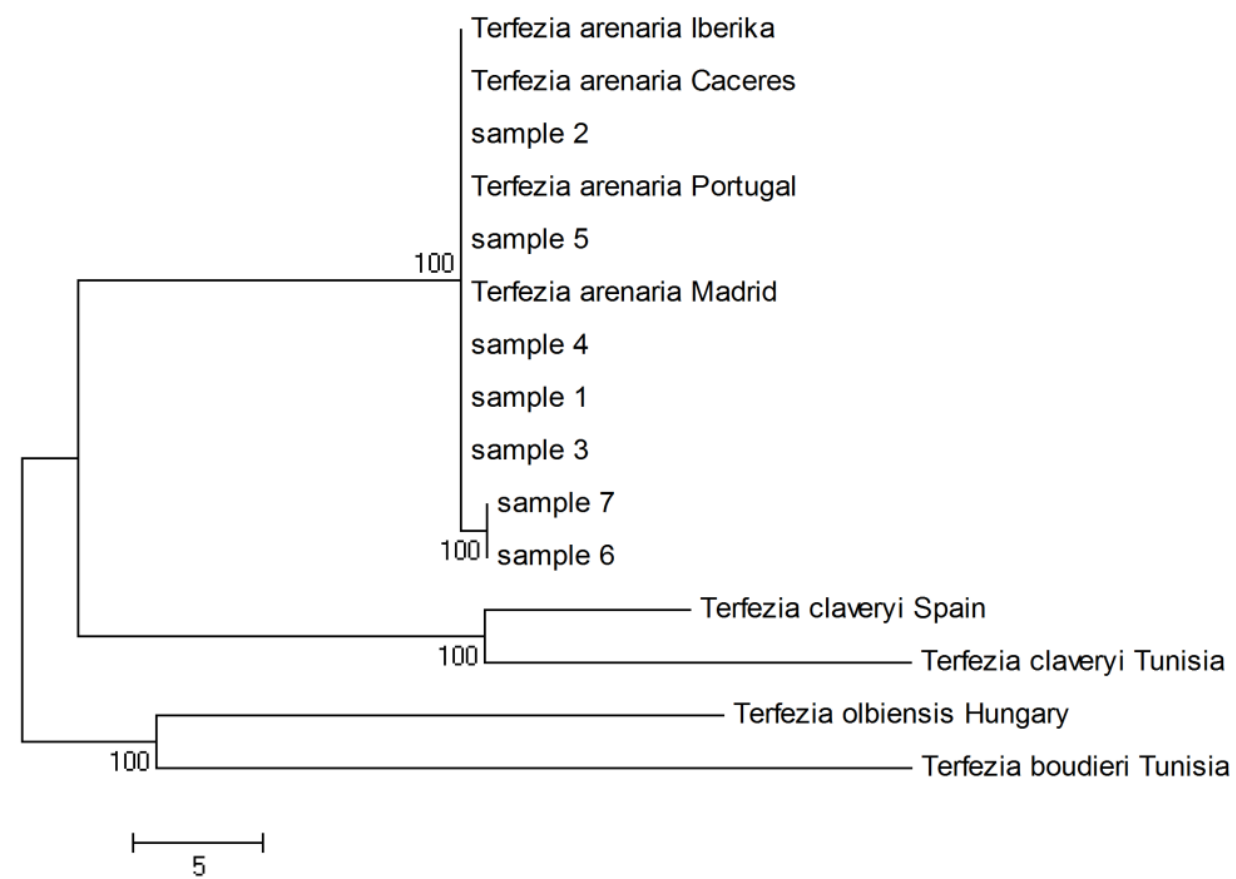

Fig. 4: Genealogic tree of Terfezia arenaria from north-eastern Algeria

According to GenBank database, all samples are 100\% Terfezia arenaria except of samples 6 and 7 that are $99 \%$ identic to T. arenaria. They may represent particular subspecies, a hypothesis to verify with further PCR on several T. arenaria samples. 

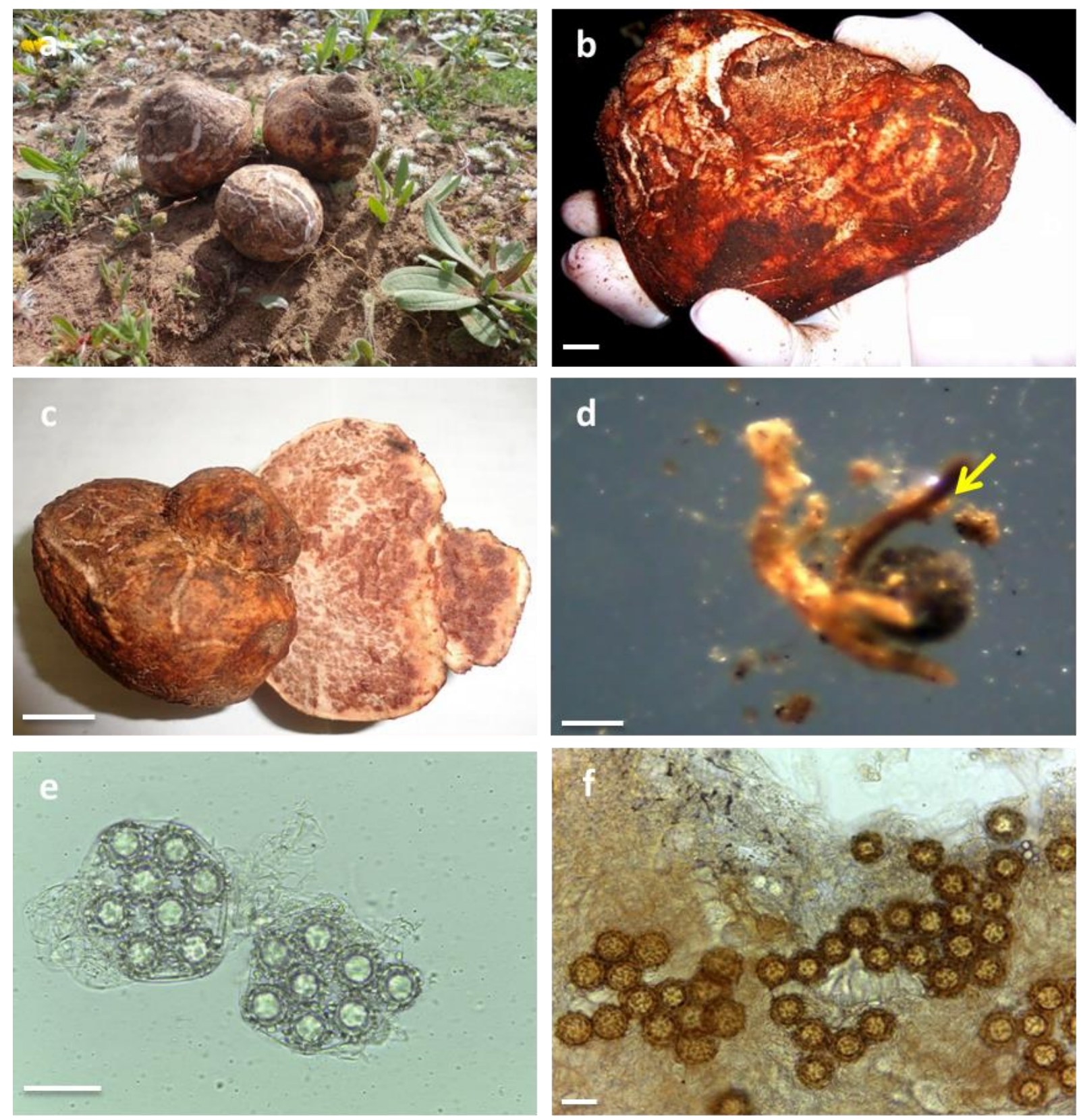

Fig. 5: Terfezia arenaria (Moris) Trappe (1971) (Photograph ๑ DAFRI A)

a: Ascocarps from site 3, b: biggest ascocarp of spring 2012 harvested from site 4, c: gleba of mature ascocarp, d:microscopic ascomata, e: asci under light microscopy, f: ascospores in their original location [b, $\mathbf{c}$ bar $=1 \mathrm{~cm} ; \mathbf{d}, \mathbf{e}, \mathbf{f}$ bar $=20 \mu \mathrm{m}]$

\subsubsection{Tuber gennadii (Chatin) Patouillard 1903}

Exclusive for site 7, Tuber gennadii is a little known truffle, often mistaken with Tuber asa Tulasne and Tulasne (1851), regarded as an "intermediate" between Tuber and Terfezia species [27]. It is a very small species whose size is about $2 \mathrm{~mm}-15 \mathrm{~mm}$, characterised by a very dark brown peridium, and a spongious gleba with a particular aspect. Asci 

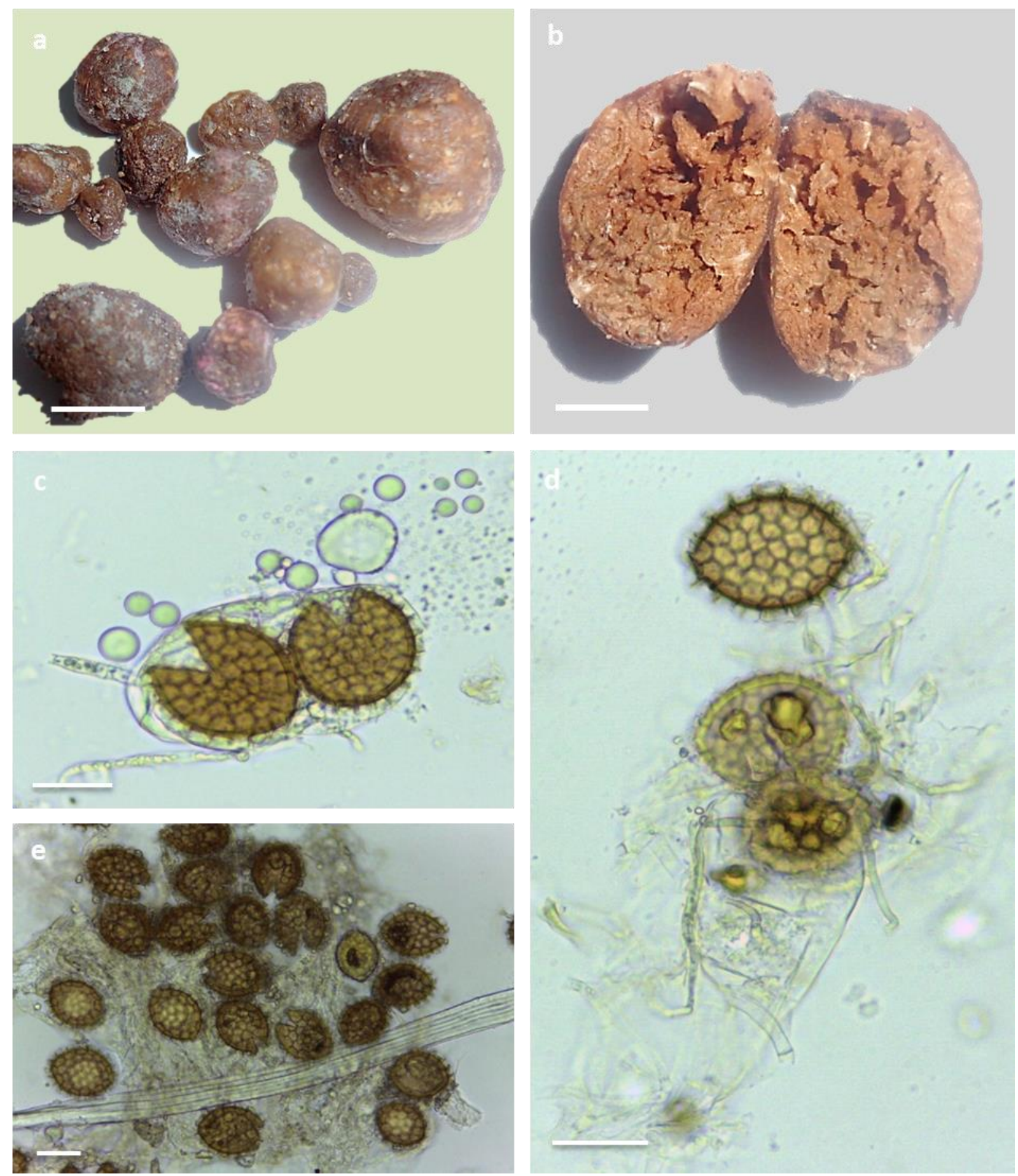

Fig. 6: Tuber gennadii (Chatin) Patouillard 1903 (Photograph @ DAFRI A)

a: ascoma, b: gleba showing a characteristic spongy appearance, c: ascus containing two ascospores under light microscopy $\mathbf{d}$ : ascospores showing their lipidic granules, e: ascospores and mycelia in their original location. [a, b bar $=1 \mathrm{~mm} ; \mathbf{c}, \mathbf{d}, \mathbf{e}$ bar $=20 \mu \mathrm{m}]$.

are ellipsoid to clavate or pyriform, thick-walled, long stalked with an average diameter of 52.5-82.5 $\mu \mathrm{m}$. Asci contain only 1 or 2 ascospores, globose to broadly ellipsoid or citriform, 
yellow, yellow brown at maturity, translucent, ornamented with spines forming a regular reticulum with polygonal meshes. Their sizes are about 32.5-42.5 $\mu \mathrm{m}$ for longitudinal diameter and 19.5-25.5 $\mu \mathrm{m}$ for transversal one (Fig. 6).

\section{DISCUSSION}

Previous studies describe desert truffles as exclusive to arid and semi-arid areas $[18,9,2,5$, 28a]. In Algeria, they are mentioned in the arid and semi-arid zones [10, 11]. However, very few references mention that desert truffles occur in areas with Mediterranean climate and a wide range of soil properties [28b]. Thus, the present paper strengthens these results by highlighting the being of desert truffles in sub-humid and humid regions of northeastern Algerian coastal dunes, refuting thereby the idea of their exclusiveness to dry climates.

Tuberaria guttata as described previously, reminds Quezel et Santa [29] and Pottier-Alapetite [30] descriptions. The plant is known as desert truffles mycorrhistic partner [17] but poorly studied as so.

Terfezia arenaria, present in almost all sites, is shown to be the most commonly encountered sandy truffle, which suggests it as a species with a large spectrum of adaptation to environment pedoclimatic conditions. Soil analysis, show that Terfezia arenaria grows in acid sandy-loam soil, which is conform to earlier knowledge on this species. Demonstrated results show also that Terfezia arenaria is well adapted to soils with different percentages on organic matter content.

Contrary to Terfezia arenaria, Tuber gennadii is exclusive to site 7. A site that receives the relatively, highest precipitation (1000 mm/year), and differs significantly from the other sites, by a very acidic $\mathrm{pH}$ and a very poor rate in total and assimilable phosphorus [Table 1]. This exclusivity could be explained by the pedoclimatic conditions of that field, supposed to be the most appropriate for this species; a hypothesis that might be verified in further studies.

In fact, research conducted on Algerian desert truffles mention nine species belonging to three different genera. Four Terfezia species: Terfezia arenaria, Terfezia boudieri, Terfezia claveryi and Terfezia leptoderma, two Tirmania species: Tirmania pinoyi and Tirmania nivea, and three Picoa species: Picoa juniperi, Picoa lefebvrei and Picoa carthusiana [17, 31, 10, 11]. The same species were recorded in Tunisia [32, 33]. In Morocco, in addition to desert 
truffles of the genera: Terfezia, Tirmania and Picoa, Tuber asa and Tuber oligospermum are recorded $[4,18]$. This report is therefore the first to mention the possibility of finding different subspecies of Terfezia arenaria and the first to ratify the being of Tuber gennadii in Algeria, adding, consequently, a new species to the list above.

\section{CONCLUSION}

It has been demonstrated that desert truffles grow very well in northeastern Algerian costal dunes, on acid sandy-loam soils in association with Tuberaria gutatta (L.) Fourr. 1868, proved as desert truffles symbiotic partner. Two sandy truffle species are recorded: Terfezia arenaria (Moris) Trappe (1971) and Tuber gennadii (Chatin) Patouillard 1903, recorded for the first time in Algeria.

This first paper on northeastern Algerian desert truffles would provide a support for both ensuing and later studies that should emphasize other truffle fields amongst these coastal dunes, not only in the previously studied region but all over the length of the dune chains, from El-Tarf to the municipality of Skikda. Furthermore, it is a crucial step before studying the possibility to produce these appreciated mushrooms instead of their picking in the wild. Studies on natural and synthesized Tuberaria guttata-desert truffle association are underway. Molecular identification of Tuber gennadii and verification of Terfezia arenaria subspecies are planned as soon as samples are available.

\section{ACKNOWLEDGEMENTS}

We are very grateful to Dr. Asuncion Morte, Juan Julian and Dr. Pedro Sanchez (Universidad de Murcia, Spain) respectively for help with molecular identification of Terfezia arenaria and authentication of Tuberaria guttata species. We thank Mireille Lenn, Ita and Claude (Belgic) for their kind contribution in Tuber gennadii identification. Our gratitude goes also to forests conservancy (El-Tarf, Algeria) for precious help, Mr. Hassini for geographical cards and Mr. Merabet for access to site 3. All truffle harvesters who were too helpful on the field are greatly thanked. 


\section{REFERENCES}

[1] Bokhary H A, Parvez S. Soil mycoflora from truffle native areas of Saudi Arabia. Mycopathologia, 1992, 118:103-107.

[2] Turgemen T, Ben Asher J, Roth-Bejerano N. Kagan-Zur V, Kapulnik Y, Sitrit Y. Mycorrhiza, 2011, 21:623-630, doi 10.1007/s00572-011-0369-z

[3] El Enshasy H.A, Hatti-Kaul R. Trends Biotechnol., 2013, (12):668-77, doi: 10.1016/j.tibtech.2013.09.003

[4] Moreno-Arroyo B, Recio J, Gomez J, Pulido, E.. Tuber oligospermum from Morocco. N. Amer. Fl., ser. 2001, 2, 1:25.

[5] Navarro-Rodenas A, Lozano-Carrillo M, Pérez-Gilabert M, Morte A. Mycorrhiza, 2011, 21:247-253, doi 10.1007/s00572-010-0329-z.

[6] Trappe J, Calaridge A, Arora D, Smit A. Désert truffles of the African Kalahari: Ecology, Ethnomycology, and Taxonomy. Economic Botany, 2008, 62 (3).

[7] Omer E A, Smith D L, Wood K V, El-Manshawi B S. The volatiles of desert truffle: Tirmania nivea. Plant foods for human nutrition, 1994, 45:247-249.

[8] http://www.elnaggarzr.com/en/main.php?id=19

[9] Morte A, Zamora, M, Gutierrez A, Honrubia M. Desert truffle cultivation in semi-arid mediterranean areas. In Azcon-Aguilar C, Barea J M, Gianinazzi S, Gianinazzi-Pearson V (Eds.), Mycorrhizas: Functional processes and ecological impact. Springer-Verlag. Berlin Heidelberg, 2009, pp. 221-234

[10] Zitouni-Haouar F. E-H, Fortas Z, Chevalier G. Mycorrhiza, 2014, doi $10.1007 / \mathrm{s} 00572-013-0550-7$

[11] Bradai L, Bissati S, Chenchouni H, Amrani K. Int J Biometeorol., 2014, doi $10.1007 / \mathrm{s} 00484-014-0891-8$

[12] Direction Générale des forêts (DGF). 2003. Fiche descriptive sur les zones humides Ramsar : Lac Noir, Wilaya d'El-Tarf.

[13] Peel MC, Finlayson B L, McMahon T A. 2007. Updated world map of Koppen-Geiger climate classification. Hydro. Earth Syst. Sci. Discuss., 4, 439-473.

[14] Joleaud L. 1936. Etude géologique de la région de Bône-la Calle. B.S.G.A. (2), n 12, 
199 p., 25 fig., 2 tabl. 4 pl.

[15] Direction de Conservation des Forêts (DGF). 2007. Carte $\mathrm{n}^{\circ} 5$ : Principaux ensembles topographiques, Wilaya d'El-Tarf.

[16] Baize D. Guide des analyses en pédologie : choix, expression, présentation, interprétation. INRA, 2000, 245, pp. 33-110.

[17] Fortas Z, Chevalier G. Effet des conditions de culture sur la mycorhization de l'Helianthemum guttatum par trois espèces de terfez des genres Terfezia et Tirmania d'Algérie. Can J Bot, 1992, 70 :2453-2460.

[18] Khabar L, Najim L, Janex-Favre M, Parguey-Leduc A. Contribution à l'étude de la flore mycologique du Maroc. Les truffes marocaines (Discomycètes). Bull. Soc. Mycol. Fr., 2001, 117 (3), pp. 213-229.

[19] Loizides M, Hobart C, Konstandinides G, Yiangou Y. 2011, 13: 17-21, doi:10.1016/j.fl dmyc.2011.12.004, 2011.12.004.

[20] Slama A, Fortas Z, Neffati M, Khabar L, Boudabous A. Etude taxinomique de quelques Ascomycota hypogés (Terfeziaceae) de la Tunisie méridionale. Bull. Soc. Mycol. Fr., 2006, 122 (2-3), pp. 187-195.

[21] Bordallo J J, Rodriguez A, Muñoz-Mohedano J M, Suz L M, Honrubia M, Morte A. Five new Terfezia species from the Iberian Peninsula. Mycotaxon, 2013, doi. 10.5248/124.189

[22] Hall TA. BioEdit: a user-friendly biological sequence alignment editor and analysis program for Windows 95/98/NT. Nucl. Acids Symp. Ser., 1999, 41: 95-98

[23]http://blast.ncbi.nlm.nih.gov/Blast.cgi?PROGRAM=blastn\&PAGE_TYPE=BlastSearch\& $\underline{\text { LINK_LOC }=\text { blasthome }}$

[24] Tamura K, Dudley J, Nei M, Kumar S. Mol. Biol. Evol., 2007, 24: 1596-1599. doi:10.1093/molbev/msm092.

[25] Eck RV, Dayhoff MO. Atlas of protein sequence and structure. National Biomedical Research Foundation, Silver Springs, Maryland, 1966

[26] Rzhetsky A, Nei M. A simple method for estimating and testing minimum evolution trees.Mol. Biol. Evol., 1992, 9: 945-967.

[27] Agnello C, Kaounas V. Tuber asa and T. gennadii. A close morphological study of two 
species often confused in the past with a brief historical bibliographic summary. Ascomycete.org, 2011, 3 (4) : 65-74

[28a] Kovacs G M, Trappe J M. In Kagan-Zur V, Roth-Bejerano N, Sitrit Y, Morte A (Eds.), Soil Biology, Springer Berlin Heidelberg, 2014， doi 10.1007/978-3-642-40096-4, pp. 21-37. [28b] Bonifacio E, Morte A. In Kagan-Zur V, Roth-Bejerano N, Sitrit Y, Morte A (Eds.), Soil Biology, Springer Berlin Heidelberg, 2014, doi 10.1007/978-3-642-40096-4, pp. 57-67.

[29] Quezel P, Santa S. Nouvelle flore de l'Algérie et des régions désertiques méridionales. C.N.R.S. Paris, 1963, 636 p

[30] Pottier-Alapetite G. Flore de la Tunisie : Angiospermes - Dicotylédones. - Publ. Ministère de l'Enseignement Sup. et de la Recherche Scientifique et du Min. de l'Agriculture, Tunis (Tunisie), 1979-1981, vol. 1 Apétales et Dialypétales, 651 p. - vol. 2 Gamopétales, 529 p

[31] Fortas Z, Bellahouel-Dib S. Extraction des substances bioactives des terfez d'Algérie et mise en évidence de leur activité antimicrobienne. Revue des régions arides, 2007, 1 : $280-282$

[32] Slama A, Nefatti M. Les truffes de la Tunisie méridionale: Etude écologique et mycologique. Revue des régions arides, 2004, 15 : 3-52.

[33] Sbissi I, Neffati M, Boudabous A, Gtari M. Diversity of the desert truffle Terfezia boudieri Chatin. In southern Tunisia. Can. J. Microbiol, 2011, 57 (7), 599-605

\section{How to cite this article:}

Dafri A, Beddiar A. Desert truffles from northeastern Algerian coastal dunes: Ecology, Identification and Symbiosis. J. Fundam. Appl. Sci., 2017, 9(1), 153-169. 